\title{
An Econometric Investigation of the FDI-Economic Growth Nexus in Nigeria
}

\author{
Abraham, Ochoche \\ AC-Ogbonna, Chris \\ Department of Economics \\ Veritas University \\ Bwari Area Council, Abuja, Nigeria \\ Corresponding Author: abochoche@gmail.com
}

This study employs autoregressive distributed lag (ARDL) framework to investigate the existence and nature of the foreign direct investment (FDI) - economic growth nexus using annual data of FDI, gross domestic product (GDP) which was used as proxy for economic growth, exchange rate, inflation, trade openness (computed as sum of exports and imports as a percentage of GDP) for the period 1981 to 2017. To set this study apart, the possible effects of structural breaks in the data was not ignored. The findings revealed that FDI in Nigeria has no significant impact on economic growth during the study period. Exchange rate on the other hand does have a negative and statistically significant relationship with economic growth. Inflation and trade openness have no significant impact on economic growth. Given the study findings, it is recommended that the monetary authority continues with its current flexible exchange rate regime by intervening in the foreign exchange market as much as necessary. Also, the monetary authority should consider exchange rate targeting as a monetary policy framework as against the current monetary targeting framework or a suitable combination of both frameworks.

Keywords: ARDL, Econometric, Economic growth, FDI, Robustness, Stability

JEL Classification: C01, C10, C22

\subsection{Introduction}

Foreign Direct Investment (FDI) is one of the three components of international capital flows, besides the portfolio investment and other flows like bank loans. Formally, FDI is defined thus: "Foreign direct investment reflects the objective of obtaining a lasting interest by a resident entity in one economy ("direct investor") in an entity resident in an economy other than that of the investor ("direct investment enterprise"). The lasting interest implies the existence of a long-term relationship between the direct investor and a significant degree of influence on the management of the enterprise." (IMF, 1993 and OECD, 1996). This definition clearly shows the difference between FDI and the other two components of international capital flows. This definition clearly shows the difference between FDI and the other two components of international capital flows. More succinctly put, FDI is the investment made to acquire a lasting management interest (normally 10\% or more of the ordinary share or voting power) in big enterprises operating outside the economy of the investor.

Since the enthronement of democracy in 1999, the government of Nigeria has taken a number of measures necessary to woo foreign investors into Nigeria. These measures include the repeal of laws that are inimical to foreign investment growth, promulgation of investment law, various overseas trips for image laundry by the president, among others. More recently, the Executive Order 001 of 2017 prescribes the policy of the Federal Government to create an enabling environment for businesses and entrench measures and strategies aimed at improving the ease of doing business in Nigeria, by promoting transparency and efficiency in the conduct of public business. This was in line with its commitment to the promotion of domestic and foreign investments, creation of employment and stimulation of the national economy. Many Studies abound on Foreign Direct Investment (FDI) and its Performance on economic growth. There exists myriad of studies on FDI and economic growth in Nigeria, but to the best of our knowledge, none of these studies had taken into account the various macroeconomic policy reforms that have taken place in Nigeria by accounting for structural breaks in the series. Also, all of these studies used GDP data pre-rebasing; none exists to the best of our knowledge that investigated FDI-GDP nexus post-rebasing exercise. Whatever results previous studies had obtained might no longer hold in the era of rebased GDP. The dearth of such studies motivated this study.

The main objective of this study therefore, is to investigate the nature of the relationship between FDI and Nigeria's economic growthwithin the period of the study. In achieving this overall objective, we will also ascertain the impact of Naira/Dollar exchange rate, inflation and trade openness on economic growth in Nigeria. 
The remainder of the paper is structured as follows: Section two contains the review of some extant literature. Section three explains the data and methodology used for the study, section four contains data presentation and analysis and section five presents conclusion and policy recommendations.

\subsection{Literature Review}

\subsection{Theoretical Framework}

The theoretical underpinning for this study can be found in the new theory of endogenous growth which was originally developed by Arrow (1962) and Shell (1966) and later extended by Romer (1986, 1990), Lucas (1988), and Grossman and Helpman (1994). The investigation of the relationship between DI, FDI, finance development, trade openness, and economic growth is based on the standard model of growth where economic output is determined by total factor productivity and the conventional inputs. However, the new theory of endogenous growth states that total factor productivity is determined endogenously by economic factors, such as FDI inflows and technological progress (Belloumi, 2014). According to the literature on the FDI-led growth hypothesis (see DeMello, 1997; Borensztein et al. 1998; Ozturk, 2007), FDI may promote knowledge transfers through labor training and skill acquisition and by the adoption of new management practices and better organizational arrangements.

\subsection{Empirical Literature}

There exists a plethora of studies on the impact of FDI on economic growth with many believing that the study of the impact of FDI and economic growth is inconclusive. Belloumi and Alshehry (2018) investigated the causal links between domestic capital investment, foreign direct investment (FDI), and economic growth in Saudi Arabia over the period 1970-2015 by using the autoregressive distributed lag (ARDL) bounds testing to cointegration approach. The results show that in the long term there are negative bidirectional causality between non-oil GDP growth and FDI, negative bidirectional causality between non-oil GDP growth and domestic capital investment, and bidirectional causality between FDI and domestic capital investment. FDI affects negatively domestic capital investment in the short run, whereas domestic capital investment affects negatively FDI in the long run. Both finance development and trade openness affect positively non-oil GDP growth, FDI inflows and domestic capital investment in the long run.

Oyatoye, Arogundade, Adebisi, and Oluwakayode (2011) in a study of Foreign Direct Investment, Export and Economic growth in Nigeria over the period of 1987- 2006 found that there is a positive relationship between Foreign Direct Investment and gross domestic product (GDP). The result further showed that one naira increase in the value of Foreign Direct Investment will lead to N104.749 increase in Gross Domestic Product. Zhang (2001) argued that FDI has positive growth impact that is similar to domestic investment along with partly alleviating balance of payment deficit in the current account. He opined that via technology transfer and spillover efficiency, the inflow of direct foreign investment might be able to stimulate a country economic performance.

Onyeagu and Okeiyika (2013) using panel data for 25 transition economies for the period, 1990-1998 conclude that Foreign Direct Investment for set of countries is influenced by economy clusters (agglomeration), market size, the low cost of labour and abundant natural resources. The finding also shows significant relationship between institutions, trade openness, low restrictions and Foreign Direct Investment inflows Their result discovers that growth rate, degree of openness, absence of corruption, infrastructural development and corporate tax rate are important determinants of Foreign Direct Investment. Makola (2003) using panel data for the situation, found that Japanese Foreign Direct Investment is strongly influenced by host country's macroeconomic conditions and the size of the host country market. Alejandro (2010) explained that FDI plays an extra ordinary and growing role in global business and economics.

It can provide a firm with new markets and marketing channels, cheaper production facilities access to new technology products, skills and financing for a host country or the foreign firms which investment, it can provide a source of new technologies, capital processes products, organization technologies and management skills and other positive externalities and spillover that can provide a strong impetus to regional economic growth.

Nwankwo (2013) investigated the impact of globalization on foreign direct investment in Nigeria-since the world has become a global village. The methodology used is purely descriptive and narrative and the data used is secondary. It was found out that foreign direct investment (FDI) has been of increased benefit to Nigeria in the area of employment, transfer of technology, encouragement of local enterprises etc. But there are certain impediments to the full realization of the benefits of foreign direct investment. Results from extant literature on the impact of FDI on economic growth in Nigeria have been mixed. For example, on the one hand researchers like Akiri et al. (2016) in their study on the impact of foreign direct investment on the growth of Nigerian economy over the period, 1981-2014, found that FDI has significant positive impact on the growth of Nigerian economy (a position supported by Adikwe et al. 2015; John 2016; Umoh et al. 2012 and Adeleke et al.2014). On the other hand, Olokoyo, (2012) in examining the effects of Foreign 
Direct Investment (FDI) on the development of Nigerian economy concluded that there was no support for the view of a robust link between FDI and economic growth in Nigeria as suggested by extant previous literatures and this position was supported by Ugochukwu et al. (2013) among others.

\subsection{Data and Methodology}

\subsection{Method of Data Collection and Sources of Data}

The data for this research was gathered from entirely secondary sources from the Data Management Office in the Statistics Department of the Central Bank of Nigeria. The data includes data for the Rebased Gross Domestic Product at constant basic prices (i.e. Real GDP), Exchange Rate (EXCH), Inflation (INFL), Trade Openness (TOP) (computed as sum of exports and imports as a percentage of GDP (as in Olufemi, 2004)) and Foreign Direct Investment (FDI).

\subsection{Model Specification}

Model specification is inspired by the econometric model of Trinh and Nguyen (2015) which was derived from a production function framework based on the theoretical models of the neoclassical and endogenous growth as well as various empirical analysis models such as Borensztein et al. (1998), Hoang et al. (2010), and Adhikary (2015) in which FDI was incorporated as one of the factor inputs, along with exchange rate, inflation and trade openness. The model for this study is specified as follows:

$\mathrm{RGDP}=f(\mathrm{FDI}, \mathrm{INFL}, \mathrm{EXCR}, \mathrm{TOP})$

In static ${ }^{1}$ form the model of equation (1) becomes:

$L N(R G D P)=\beta_{0}+\beta_{1} L N(F D I)+\beta_{2} I N F L+\beta_{3} L N(N E R)_{+} \beta_{4} T O P_{+} \mu$

where:

LNRGDP is log of Real Gross Domestic Product, LNNER is log of Exchange Rate, INFL is Inflation rate, LNFDI is $\log$ of Foreign Direct Investment, TOP is Trade openness (sum of exports and imports as a percentage of GDP), $\beta_{0}$ is a constant representing the slope of regression, $\beta_{1}, \beta_{2}, \beta_{3}$ and $\beta_{4}$ are coefficients of elasticities. They show how a unit change in the independent variable affects the dependent variable, and $\mu=$ Error term and it is incorporated in the equation to accommodate all other factors that may influence GDP but are not captured in this study.

It is expected that FDI inflows and trade openness would have positive impacts on economic growth whereas exchange rate, inflation rate and interest rate are expected to have negative relationship with economic growth in Nigeria.

\subsection{Estimation Procedure}

The Pesaran et al. (2001) cointegration technique is a 2-stage procedure for the estimation of the long-run relationship among time series variables. In the first stage, the existence of cointegration amongst the variables (bounds testing) is ascertained via the standard Wald or Fisher F-test using equation 1. The null hypothesis is that the coefficients of the lagged regressors in the error correction version of the ARDL model (equation 4) are zero i.e. $H_{0}: \delta_{1}=\delta_{2}=0$. This null is tested against the alternative hypothesis of $H_{1}: \delta_{1} \neq \delta_{2} \neq 0.2$ The second stage of estimation can only proceed once cointegration is established among the variables. At this stage, the short-run and long-run parameters are estimated ${ }^{3}$ using the following two equations:

Long-run equation:

\footnotetext{
${ }^{1}$ In a static model, variables are neither lagged nor differenced

${ }^{2}$ Pesaran et al. (2001) provide critical values to test the hypothesis, with and without time trend. The critical values are grouped into "lower" and "upper" bounds. The assumption for the lower bound is that all the variables are level stationary or I $(0)$ while the the assumption for the upper bound is that all the variables are jointly first-difference stationary i.e. I(1). To reject the null hypothesis, the calculated F-statistic must be greater than the upper bound critical value. If otherwise, a decision to fail to reject the null hypothesis is required for the model. If however the computed F-statistic lies between the lower and upper bounds, then the test result is said to be inconclusive. At this stage knowledge of the order of integration (or time series properties of the variables) is required to proceed.

${ }^{3}$ The lag length and lag criterion are chosen; the criteriaused was Schwartz (SIC). Stability and diagnostic checks are carried out for heteroscedasticity, serial correlation, linearity, stability and normality of the data.
} 


$$
\begin{aligned}
& \ln R G D P_{t}=\theta_{0}+\sum_{i=1}^{K} \theta_{1} \ln R G D P_{t-i}+\sum_{j=0}^{M} \theta_{2} \operatorname{lnFDI_{t-j}}+\sum_{r=0}^{N} \theta_{3} I N F L_{t-r}+\sum_{l=0}^{p} \theta_{4} \ln N E R_{t-l} \\
& +\sum_{s=0}^{p} \theta_{5} T O P_{t-s}+\varepsilon_{t} .
\end{aligned}
$$

Where appropriate lags would have been selected for both the dependent and independent variables using any of the information criterion after confirming the existence of long-run relationship in stage one.

The dynamic error correction term (ECT), embedded in the short run dynamic ARDL is given as:

$$
\begin{aligned}
\Delta l n R G D P_{t}= & \omega_{0}+\sum_{i=1}^{K} \omega_{1} \Delta l n R G D P_{t-i}+\sum_{j=0}^{M} \omega_{2} \Delta l n F D I_{t-j}+\sum_{r=0}^{N} \omega_{3} \Delta I N F L_{t-r}+\sum_{t=0}^{p} \omega_{4} \Delta l n N E R_{t-i} \\
& +\sum_{s=0}^{Q} \omega_{5} \Delta T O P_{t-s}+\phi E C T_{t-1}+\varepsilon_{t} .
\end{aligned}
$$

The coefficient of the error correction term (ECT) serves as a measure of the speed of adjustment. It represents the rate at which real GDP will converge back to a new equilibrium in the long run following a shock to the system. It is expected to be negative and significant and less than one in absolute value for the model to be stable. The model is subjected to a number of important diagnostics tests such as the normality, heteroscedasticity, autocorrelation, linearity and stability tests.

\subsection{Data Analysis and Presentation of Results}

\subsection{Descriptive Statistics and Unit Root Test}

\subsubsection{Descriptive Statistics}

Preliminary analysis was done to determine if the data was normally distributed or not. A distribution is normally distributed if "skewness" is approximately zero and "kurtosis" is three. The probability value of the Jarque-Bera statistics is an indicator of whether the distribution is normal or not. The null $\left(\mathrm{H}_{0}\right)$ for Jarque-Bera statistics test is that the distribution is normal. In this study, a 5\% rejection region is employed and according to Brooks, (2014), this should be sufficient for our small dataset.

As shown in Table 1, based on values for "skewness", "kurtosis" and the probability of the Jarque-Bera statistics, four

\begin{tabular}{|c|c|c|c|c|c|}
\hline & LNRGDP & LNNER & LNFDI & INFL & TOP \\
\hline Mean & 17.15279 & & 10.91108 & 20.10297 & 14.39081 \\
\hline Median & 16.92677 & 4.529297 & 11.61994 & 13.67000 & 9.140000 \\
\hline Maximum & 18.04996 & 5.722887 & 14.12317 & 76.76000 & 45.61000 \\
\hline Minimum & 16.43867 & -0.494255 & 5.577085 & 0.220000 & 0.100000 \\
\hline Std. Dev. & 0.548970 & 1.961499 & 2.878694 & 18.46380 & 14.58010 \\
\hline Skewness & 0.393030 & -0.748097 & -0.642626 & 1.605938 & 0.655371 \\
\hline Kurtosis & $\begin{array}{l}1.696252 \\
\end{array}$ & 2.241403 & 2.048184 & 4.604984 & 2.035270 \\
\hline Jarque-Bera & 3.573040 & 4.338356 & 3.943313 & 19.87535 & 4.083487 \\
\hline Probability & 0.167542 & 0.114272 & 0.139226 & 0.000048 & 0.129802 \\
\hline & 634.6532 & 1242989 & 403.7099 & 743.8100 & 532.4600 \\
\hline Sum Sq. Dev. & 10.84924 & 138.5092 & 298.3276 & 12272.83 & 7652.856 \\
\hline Observations & 37 & 37 & 37 & 37 & 37 \\
\hline
\end{tabular}
of the variables are normally distributed namely LNRGDP, LNNER, LNFDI and TOP while INFL is not normally distributed.

Table 1: Descriptive Statistics

\subsection{Formal Pre-tests: Unit root tests and Cointegration test}

\subsubsection{Unit root tests}

Time series data must first be tested for stationarity before they can be used to carry out any form of analysis. As mentioned earlier, this study uses KPSS and the DF-GLS. As can be seen from Tables $2 a$ and $2 b$, the results of the stationarity tests show that three variables namely LNRGDP, LNFDI and LNNER were non-stationary at level while INFL and TOP were ${ }^{4}$ at critical value of 5\%. However, on applying the tests to the first difference of LNRGDP, LNFDI and LNNER the series become stationary at critical value of 5\%. Table $2 \mathrm{c}$ gives a summary of the unit root test result.

\section{Table 2a: Unit Root Test without Structural Breaks}

\footnotetext{
${ }^{4}$ If the computed t-statistics is less than the 5\% critical value then we accept the null for KPSS (Null: variable is stationary) and reject the null for DF-GLS (Null: variable has a unit root).
} 


\begin{tabular}{|l|c|c|c|c|c|c|}
\hline & \multicolumn{2}{|c|}{ LEVEL } & \multicolumn{3}{c|}{ KPSS } \\
\hline & \multicolumn{3}{|c|}{ Critical } & & \multicolumn{3}{c|}{} & $\begin{array}{c}\text { Critical value } \\
\text { at 5\% }\end{array}$ \\
\hline Variables & SIC Lag & t-Statistics & $\begin{array}{c}\text { value at 5\% } \\
\text { vandwidth }\end{array}$ & t-Statistics & Bantion \\
\hline LNRGDP & 1 & $-1.797832^{* * *}$ & -3.190000 & 4 & $0.189341^{* * *}$ & 0.146000 \\
\hline LNFDI & 0 & $-0.179531^{* *}$ & -1.950394 & 5 & $0.680403^{* *}$ & 0.463000 \\
\hline LNNER & 0 & $-1.251038^{* * *}$ & -3.190000 & 4 & $0.199858^{* * *}$ & 0.146000 \\
\hline INFL & 0 & $-3.170854^{* *}$ & -1.950394 & 3 & $0.314218^{* *}$ & 0.463000 \\
\hline TOP & 0 & $-3.421826^{* * *}$ & -3.190000 & 3 & $0.111923^{* * *}$ & 0.146000 \\
\hline
\end{tabular}

*model without constant and trend, **model with constant but no trend, ***model with constant and trend. The optimal lag orders for Dickey-Fuller Generalized Least Squares (DF-GLS) tests are determined using the Schwarz criterion, while the bandwidth for Kwiatkowski-Phillips-Schmidt-Shin (KPSS) test is determined by the Newey-West using Bartlett kernel. (see Appendix for details).

Table 2b: Unit Root Test without Structural Breaks

\begin{tabular}{|c|c|c|c|c|c|c|}
\hline & \multicolumn{2}{|c|}{ FIRST DIFFERENCE } & & & & \\
\hline & \multicolumn{3}{|c|}{ DF-GLS } & \multicolumn{3}{|c|}{ KPSS } \\
\hline Variables & SIC Lag & t-Statistics & $\begin{array}{c}\text { Critical } \\
\text { value at } 5 \%\end{array}$ & Bandwidth & t-Statistics & $\begin{array}{c}\text { Critical value } \\
\text { at } 5 \%\end{array}$ \\
\hline LNRGDP & 0 & $-2.766389 * *$ & -1.950687 & 3 & $0.321176 * *$ & 0.463000 \\
\hline LNFDI & 0 & $-7.962265 * *$ & -1.950687 & 1 & $0.305839 * *$ & 0.463000 \\
\hline LNNER & 0 & $-5.435283 * * *$ & -3.190000 & 4 & $0.065369 * * *$ & 0.146000 \\
\hline \multicolumn{7}{|l|}{ INFL } \\
\hline TOP & & & & & & \\
\hline
\end{tabular}

*model without constant and trend, **model with constant but no trend, ***model with constant and trend. The optimal lag orders for Dickey-Fuller Generalized Least Squares (DF-GLS) tests are determined using the Schwarz criterion, while the bandwidth for Kwiatkowski-Phillips-Schmidt-Shin (KPSS) test is determined by the Newey-West using Bartlett kernel. (see Appendix for details).

As mentioned earlier, to the best of our knowledge, no similar study has accounted for the various socio-historical, socio-political and socio-economic events that had taken place in Nigeria within their study period. Perron (1989), argues that in the presence of a structural break, the standard ADF tests are biased towards the non-rejection of the null hypothesis. According to him, "Most macroeconomic time series are not characterized by the presence of a unit root. Fluctuations are indeed stationary around a deterministic trend function..." (1989, pp. 1361). Therefore, to stand this study out from others, we had tested for the stationarity as well as the significance of structural breaks in the series endogenously using the method of Zivot and Andrews (1992) ${ }^{5}$ and the result is shown in Table 2d.

Table 2c: Summary of Stationary Test Result

\begin{tabular}{lr}
\hline Variables & $\begin{array}{l}\text { Order of } \\
\text { Integration }\end{array}$ \\
\hline LNRGDP & $\mathrm{I}(1)$ \\
LNFDI & $\mathrm{I}(1)$ \\
LNNER & $\mathrm{I}(1)$ \\
INFL & $\mathrm{I}(0)$ \\
TOP & $\mathrm{I}(0)$ \\
\hline
\end{tabular}

Table 2d: Test for Presence ofStructural Breaks

\begin{tabular}{lcc}
\hline \multicolumn{1}{r}{ Variables } & Break Dates & T-statistics \\
\hline LNNER & 1999 & -7.204118 \\
INFL & 1999 & -8.265154 \\
LNRGDP & 2009 & -4.993273 \\
LNFDI & 1995 & -9.044080 \\
TOP & 2004 & -7.176020 \\
\hline
\end{tabular}

Note: Critical values are -5.35 and -4.86 for $1 \%$ and $5 \%$ levels of significance respectively ${ }^{6}$ (see Appendix for more details).

Evidence from Table $2 \mathrm{~d}$ further shows that even when structural breaks are considered, all the variables are stationary ${ }^{7}$ and since ARDL Bounds test for cointegration is the adopted methodology, this information suffices.

\subsubsection{Cointegration Test and Estimations}

Due to our small sample size, it would be unwise to include all the identified structural breaks identified in Table 2d, to avoid problems with degree of freedom. Because of the small sample size involved, 1999 and 2009 were considered as the breakpoints to include in our analysis because in 1998 there was a transitioning process in Nigeria from military to

\footnotetext{
${ }^{5}$ Any other single breakpoint test for unknown structural break like the Gregory and Hansen (1996) test can also be used; it is a matter of choice. Multiple breakpoint tests like Bai and Perron (2006) could not be used because of our small sample size (see Antoshin et al. 2008) ${ }^{6}$ See Salisu and Oloko (2015)

${ }^{7}$ The null hypothesis for Zivot-Andrews Unit Root Test of "unit root with structural break in the intercept" of a variable can only be rejected when Zivot-Andrew test statistic value is less than the critical values of $(1 \%, 5 \%$ \& $10 \%)$ levels. 
democratic rule with elections and all the attendants effects on the economy and also because in 2008: Q4 ${ }^{8}$ the Nigerian economy began to feel the full effect of the Great Depression that began in 2008. At the end, it was decided to go with 1999 because two variables had this date and also because it was significant at $1 \%$ significance for both variables.

Equation (4) can then be re-specified incorporating the breakpoint as equation (8).

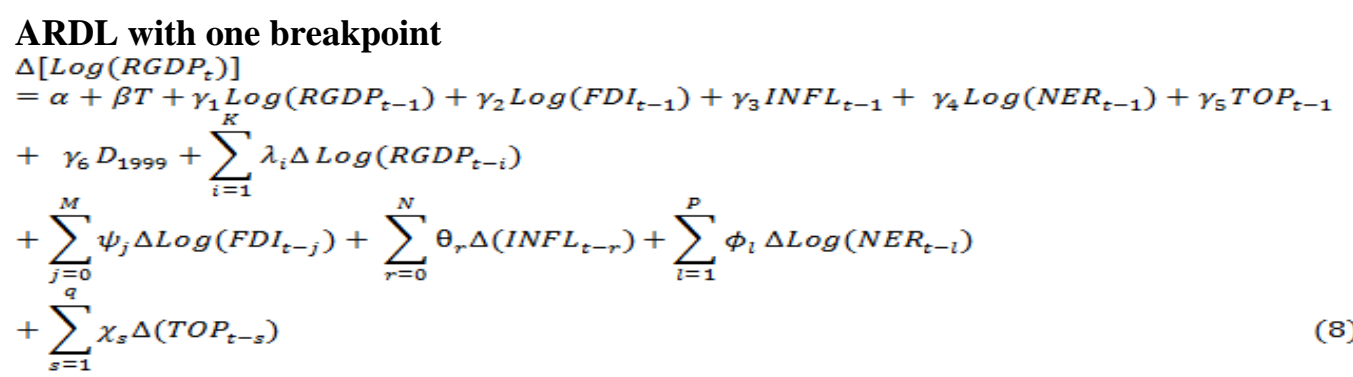

Next thing to do is to formulate an "unrestricted" error-correction model (ECM). As stated earlier, the ARDL model approach is broadly implemented in two stages to estimate the long-run relationship. In the first stage, the existence of long-run relationship is tested using the bounds test. The bounds test F-statistic must be greater than the upper bound critical values at 5\%. The results for the long-run models being tested is presented in Table 3. The computed F-statistics from the bounds test is 3.88 and this value is greater than the upper bound theoretical critical value of 3.76 at $5 \%$ level of significance. Hence, the null hypothesis of no-long run relationship can be rejected for the model. In effect, there exist a long-run relationship between economic growth (RGDP) and its determinants over the study period. This result implies that both the long run and short run models need to be estimated.

\subsubsection{Estimating the long run and short run models}

The original specification as proposed by Pesaran et al. (2001) (using the variables in our study) is given by equations (4) and (5). Both equations can be re-parameterized to estimate an unrestricted error correction model. Both the long run, short run and error correction (speed of adjustment) parameters can be estimated using either equation (4) or equation (5). The orders of the ARDL (p, q1, q2, q3, q4, q5) model in the six variables were selected by using SIC. The estimation was done using the following $\operatorname{ARDL}(3,0,0,3,2,0)$ specification and the results (obtained with EViews 9.5) are given in Tables 4 and 5.

\section{Estimating the long run model}

The long-run result is presented in Table 4 and all the coefficients are with correct sign. There is a negative and statistically significant (at 1\% level of significance) relationship between exchange rate and economic growth (RGDP). Hence, an appreciation in domestic exchange rate leads to a decline in economic growth, especially for an import dependent country like Nigeria because imported goods would be cheaper than locally produced goods, as outlined in economic theory. Specifically, a $1 \%$ appreciation in exchange rate would lead to a $0.15 \%$ growth decline (RGDP) in the economy.There is a positive but insignificant relationship between foreign direct investment and economic growth in the long run in Nigeria. Inflation is negative and statistically insignificant. On the other hand, trade openness has a positive but insignificant impact on economic growth in the long run.

\section{Estimating the short run model}

Some of the problems of instablity could stem from inadequate modelling of the short-run dynamics charaterising departures from the long-run realtionship. Hence it is important to incorporate the short-run dyamics for consistency of long-run parameters.

The dynamic error correction regression along with the coefficients of all lagged first differenced variables in the ARDL model (Short-run coefficient estimates) is reported in Table 5. Not much can be inferred from the short-run coefficients as they all show the dynamic adjustments variables.

The error correction coefficient ${ }^{9}$, estimated at -0.299255 is highly significant at the $1 \%$ level, it is correctly signed and indicates a slow speed of adjustment back to equilibrium. As noted in Bannerjee et al. (2003) as cited in Kidanemariam (2015), the fact that the error term is highly significant is further confirmation of that there exists a stable long-run

\footnotetext{
${ }^{8}$ Recall that, unlike Perron (1997), EViews (implementing Zivot and Andrews, 1992) reports the break date for the start of the new regime instead of the last date before of the old regime.

${ }^{9}$ Usually, $-1<$ ECM-1<0
} 
relationship. Also, the ECM-1 coefficient could be interpreted to mean that the deviation from long run equilibrium level of RGDP of the current period is corrected by $29.9 \%$ in the next period to bring it back to equilibrium.

Table 3: Bounds test Cointegration result.

Table 4: Long Run Estimates

Null Hypothesis: No long-run relationships exist

\begin{tabular}{lcc}
\hline \hline Test Statistic & Value & $k$ \\
\hline \hline F-statistic & 3.884338 & 5 \\
\hline \hline \multicolumn{3}{l}{ Critical Value Bounds } \\
\hline \hline \multirow{2}{*}{ Significance } & 10 Bound & 11 Bound \\
\hline \hline $10 \%$ & 2.49 & 3.38 \\
$5 \%$ & 2.81 & 3.76 \\
$2.5 \%$ & 3.11 & 4.13 \\
$1 \%$ & 3.5 & 4.63 \\
\hline \hline
\end{tabular}

\begin{tabular}{crrrr}
\hline \hline Variable & Coefficient & Std. Error & t-Statistic & Prob. \\
\hline \hline LNNER & -0.159946 & 0.049475 & -3.232865 & 0.0044 \\
LNFDI & 0.041158 & 0.042300 & 0.973001 & 0.3428 \\
INFL & -0.001549 & 0.001923 & -0.805501 & 0.4305 \\
TOP & 0.003791 & 0.003233 & 1.172664 & 0.2554 \\
DUMMY99 & 0.143154 & 0.099994 & 1.431625 & 0.1685 \\
@TREND & 0.053191 & 0.009356 & 5.685357 & 0.0000 \\
\hline \hline
\end{tabular}

Table 5: Short Run Estimates

\begin{tabular}{crrrr}
\hline \hline Variable & Coefficient & Std. Error & t-Statistic & Prob. \\
\hline \hline D(LNRGDP(-1)) & 0.342085 & 0.111909 & 3.056801 & 0.0065 \\
D(LNRGDP(-2)) & 0.394459 & 0.125597 & 3.140674 & 0.0054 \\
D(LNNER) & -0.047878 & 0.012341 & -3.879511 & 0.0010 \\
D(LNFDI) & 0.008779 & 0.008351 & 1.051255 & 0.3063 \\
D(INFL) & -0.000015 & 0.000216 & -0.069922 & 0.9450 \\
D(INFL(-1)) & 0.000654 & 0.000235 & 2.779401 & 0.0119 \\
D(INFL(-2)) & 0.001316 & 0.000258 & 5.095482 & 0.0001 \\
D(TOP) & -0.000565 & 0.000500 & -1.130211 & 0.2725 \\
D(TOP(-1)) & -0.001530 & 0.000577 & -2.652610 & 0.0157 \\
D(DUMMY99) & 0.033993 & 0.020222 & 1.681012 & 0.1091 \\
C & 4.865981 & 0.793918 & 6.129072 & 0.0000 \\
CointEq(-1) & -0.299255 & 0.049131 & -6.090980 & 0.0000 \\
\hline \hline
\end{tabular}

\section{Stability Diagnostics}

The stability of long-run coefficents is used to form the error-correction term in conjuction with the short-term dynamics. The CUSUM and CUSUMSQ developed by Brown et et al (1975)tests for stability are meant to determine the appropriateness and the stability of the modelfor making long run decision. Analysis of figures 1 and 2 showed that the plots for both the CUSUM and CUSUMSQ statistics are stable and within the 5\% critical bound. This suggests that the parameters of the model do not suffer from any structural instability over the period of study. Thus, it can be concluded that all the coefficients in the error correction model are stable.

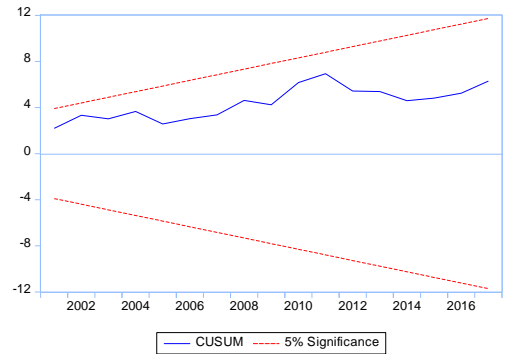

Graph for CUSUMSQ

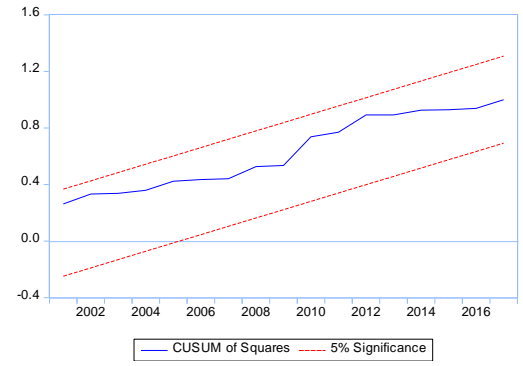

Figure 1: Graph for CUSUM
Figure 2:

\subsection{Post Estimation Procedures: Model Diagnostic and Robustness Tests}

ARDL is a linear regression model hence the underlying assumptions of classical linear regression models (CLRM) have to be verified. These assumptions as earlier highlighted are linearity, homoscedasticity, serial correlation and normality among others. The Ramsey RESET test is used for this purpose and it is meant to ascertain whether the model is linear, i.e. it is correctly specified. The test for serial correlation was done using Correlogram-Q-Statistics, Correlogram squared residuals and the Breusch-Godfrey LM tests. The test for heteroscedasticity was done using the Breusch-Pagan-Godfrey test for heteroscedasticity of errors in the regressions. The results for all the tests are contained in Tables $6-10$ as well as figure 3. 


\begin{tabular}{lccc}
\hline \hline & Value & $d f$ & Probability \\
\cline { 2 - 4 } t-statistic & 0.186524 & 18 & 0.8541 \\
F-statistic & 0.034791 & $(1,18)$ & 0.8541 \\
\hline \hline F-test summary: & & & \\
& & & Mean \\
Test SSR & Sum of Sq. & df & Squares \\
\cline { 2 - 4 } Restricted SSR & $1.52 \mathrm{E}-05$ & 1 & $1.52 \mathrm{E}-05$ \\
Unrestricted SSR & 0.007885 & 19 & 0.000415 \\
\hline \hline
\end{tabular}

Table 8: Correlogram of Residuals Squared

\begin{tabular}{|c|c|c|c|c|c|c|}
\hline Autocorrelation & Partial Correlation & & $A C$ & PAC & Q-Stat & Prob $^{*}$ \\
\hline , 미 & & 1 & -0.163 & -0.163 & 0.9889 & 0.320 \\
\hline $1 \square$ & & 2 & 0.265 & 0.245 & 3.6750 & 0.159 \\
\hline 101 & & 3 & 0.032 & 0.114 & 3.7150 & 0.294 \\
\hline 10 & [ & & -0.086 & -0.145 & 4.0176 & 0.404 \\
\hline ' $\square$ & ' & 5 & 0.360 & 0.329 & 9.4876 & 0.091 \\
\hline 10 & & 6 & -0.146 & -0.014 & 10.418 & 0.108 \\
\hline ， & & 7 & 0.165 & -0.037 & 11.647 & 0.113 \\
\hline 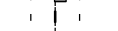 & 10 & 8 & 0.018 & 0.070 & 11.663 & 0.167 \\
\hline 101 & & 9 & -0.083 & -0.064 & 12.003 & 0.213 \\
\hline 10 & 10 & 10 & 0.059 & -0.137 & 12.182 & 0.273 \\
\hline 11 & , 1 & 11 & -0.014 & 0.121 & 12.192 & 0.349 \\
\hline 10 & 15 & 12 & -0.080 & -0.144 & 12.548 & 0.403 \\
\hline 10 & & 13 & 0.113 & 0.046 & 13.296 & 0.425 \\
\hline 101 & 15 & 14 & -0.110 & 0.042 & 14.040 & 0.447 \\
\hline 11 & 14 & 15 & -0.012 & -0.113 & 14.049 & 0.522 \\
\hline 10 & 1 d & 16 & -0.067 & -0.103 & 14.355 & 0.572 \\
\hline
\end{tabular}

\begin{tabular}{|c|c|c|c|c|c|c|}
\hline Autocorrelation & Partial Correlation & & $\mathrm{AC}$ & PAC & Q-Stat & Prob $^{*}$ \\
\hline & & & -0.100 & -0.100 & 0.3709 & 0.542 \\
\hline & & & -0.250 & -0.263 & 2.7656 & 0.251 \\
\hline & & & -0.064 & -0.132 & 2.9265 & 0.403 \\
\hline & & & 0.099 & 0.007 & 3.3301 & 0.504 \\
\hline 듬 & & & -0.184 & -0.241 & 4.7649 & 0.445 \\
\hline . 口 & & 6 & -0.149 & -0.225 & 5.7309 & 0.454 \\
\hline & & 7 & 0.288 & 0.153 & 9.4895 & 0.219 \\
\hline & & & -0.140 & -0.268 & 10.409 & 0.237 \\
\hline & & & -0.036 & -0.011 & 10.474 & 0.313 \\
\hline & & 10 & -0.014 & -0.112 & 10.484 & 0.399 \\
\hline & & 11 & 0.031 & -0.185 & 10.534 & 0.483 \\
\hline & 口 & 12 & 0.102 & 0.169 & 11.113 & 0.519 \\
\hline & & 13 & -0.064 & -0.130 & 11.349 & 0.582 \\
\hline & & 14 & 0.062 & -0.023 & 11.581 & 0.640 \\
\hline י 口 & 1 마 & 15 & -0.200 & -0.160 & 14.165 & 0.513 \\
\hline & i명 & 16 & -0.022 & -0.253 & 14.198 & 0.584 \\
\hline
\end{tabular}

Table 9: Breusch-Godfrey Serial Correlation LM Test

Table 10: Heteroscedasticity Test: Breusch-Pagan-Godfrey test

Heteroskedasticity Test: Breusch-Pagan-Godfrey

\begin{tabular}{llll} 
& & \\
& & & \\
Heteroskedasticity Test: Breusch-Pagan-Godfrey & & \\
\hline \hline & & & \\
F-statistic & 1.797599 & Prob. F(14,19) & 0.1163 \\
Obs*R-squared & 19.37349 & Prob. Chi-Square(14) & 0.1512 \\
Scaled explained SS & 9.524890 & Prob. Chi-Square(14) & 0.7960 \\
\hline \hline
\end{tabular}

Breusch-Godfrey Serial Correlation LM Test:

\begin{tabular}{llll}
\hline \hline F-statistic & & & \\
Obs*R-squared & 1.085552 & Prob. F(4,15) & 0.3987 \\
\hline \hline & 7.632791 & Prob. Chi-Square(4) & 0.1060 \\
\hline
\end{tabular}

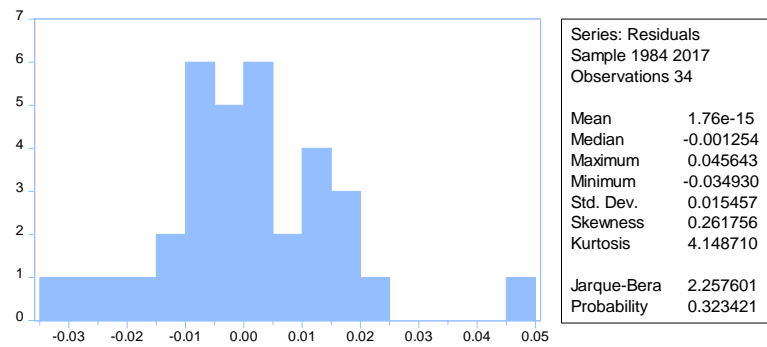

Figure 3: Histogram Normality-Test

Overall, the results reported in Tables $6-10$ and figure 5 shows no evidence of autocorrelation, there is also no evidence of heteroskedasticity, the errors are normally distributed and the model is well-specified as confirmed by the Ramsey functional form test that. Hence, it can be concluded, that the relationship between the variables is verifiable or valid.

\subsection{Findings, Conclusions and Recommendations}

\subsection{Summary of Findings}

It was discovered in this study that in the long run, there exists a negative and statistically significant relationship between exchange rate and economic growth (RGDP) in Nigeria. However, though in the long run, there exists a positive relationship between foreign direct investment and economic growth in the long run in Nigeria, it is not statistically significant. Similarly, as expected, Inflation demonstrates a negative relationship with real GDP in the long run, but it is insignificant. Trade openness too has a positive but insignificant impact on economic growth in the long run.

With regards to the main study objective, FDI in Nigeria has no significant impact on economic growth both in the long run and in the short run. Exchange rate on the other hand does have a negative and significant relationship with economic growth which is in line with a priori expectations. Inflation and trade openness have no significant impact on economic growth.

\subsection{Conclusion}

This work has investigated the nature of the relationship between foreign direct investment and economic growth for Nigeria. To achieve this, some explanatory variables were also considered in the work; exchange rate, inflation and trade openness. 
Because the dataset is small, in testing for stationarity of the variables the popular methods (ADF and P-P) were not used because they are not well suited for small dataset. Instead, we had used the DF-GLS method which was designed specifically for small dataset and KPSS for uniformity. There was the need to account for all the socio-historical, sociopolitical and socio-economic events that had taken place in Nigeria within their study period, as such test for structural breaks in the series was also carried out. Although analysis showed that the dummy were statistically significant.

Based on the outcome of the unit root test, it was determined that the study would be best carried out within and autoregressive distributed lag (ARDL) framework. Rigorous post estimation tests were carried out on the preferred model to ascertain its stability, viability and reliability for the task and results obtained showed that the model is stable and well specified.

\subsection{Policy Recommendations}

Given the significant impact of exchange rate on economic growth in Nigeria; indeed, it proved to be the only explanatory variable that was, it is recommended that the monetary authority continues with its heterodox monetary policy, particularly the current flexible exchange rate regime it introduced in June 2016, by intervening in the foreign exchange market as much as necessary to keep the Naira/US\$ exchange rate stable. Also, the monetary authority should consider exchange rate targeting as a monetary policy framework as against the current monetary targeting framework.

\section{References}

Adeleke, K. M., Olowe S.O. and Fasesin, O. O. (2014). Impact of Foreign Direct Investment on Nigeria Economic Growth, International Journal of Academic Research in Business and Social Sciences (August), Vol. 4, No. 8.

Adhikary, B. K. (2015). Dynamic Effects of FDI, Trade Openness, Capital Formation and Human Capital on the Economic Growth Rate in the Least Developed Economies: Evidence from Nepal. International Journal of Trade, Economics and Finance, 6(1), 1-7.

Adigwe P. K., Ezeagba, C. E. and Francis N. P. U. (2015). Effect of Foreign Direct Investment on Nigerian Economic Growth, European Journal of Research and Reflection in Management Sciences, Vol. 3 No. 5.

Adewuyi, A. O. (2002) Balance of Payments Constraints and Growth Rate Differences under Alternative Police Regimes, Nigerian Institute of Social and Economic Research (NISER) Monograph Series No. 10 Ibadan, Nigeria.

Agbeyebge,T. D., Stotsky, J., \&Wolde, A. (2006). Trade Liberalization, exchange rate changes, and tax revenue in sub Saharan African. Journal of Asian Economics, 17, 261-284.

Ajaji, S. I. (2003). Globalization and Africa. Journal of Africa Economics, 12, 120-150.

Akinkugbe, O. (2003). Flow of Foreign Direct Investment in Developing Countries: A Two- Part Econometric Modeling Approach" Botswana: University of Botswana Press.

Akinlo, A. E. (2004). Foreign direct investment and growth in Nigeria: an empirical investigation. Journal of Policy Modelling, 26, 627-39.

Akinmulegun, S. O. (2012). Foreign Direct Investment (FDI) and Standard of Living in Nigeria. Journal Of Applied Finance \& Banking, Vol.2, No.3, 2012, 295-309 ISSN: 1792-6580.

Akiri, S. E., Vehe, B. M. and Ijuo, O. A. (2016). Foreign Direct Investment and Economic Growth in Nigeria: An Empirical Investigation, IIARD International Journal of Economics and Business Management, Vol. 2 No.5 2016.

Alam, A. \& Shah, S. (2013). Determinants of Foreign Direct Investment in OECD Member Countries. Journal of Economic Studies. Vol. 40(4): 515-527.

Ali, A. M. \& Isse, H. S. (2002). Determinants of economic corruption: a cross-country comparison. Cato J., 22, 449.

Alotaibi, A. R. and Mishra, A. V. (2014). Determinants of International Financial Integration of GCC Markets, Chapter 31 in Emerging Markets and the Global Economy (A Handbook), pp. 749-771. https://doi.org/10.1016/B978$0-12-411549-1.00031-4$

Aminu, U. and Anono, A. Z. (2012). Effect of Inflation on the Growth and Development of the Nigerian Economy (An Empirical Analysis). International Journal of Business and Social Science, Vol.3 No.10 [Special Issue- May 2012].

Andren, T. (2007). Econometrics, Thomas and Andren Ventures Publishing, ApS. ISBN: 978-87-7681235-5.

Annaek, J. (2007). Foreign Capital Inflows an Development in Less Developed Countries.New York: McGrawHill Book Company.

Antoshin, S., Berg, A. and Souto, M. (2008). Testing for Structural Breaks in Small Samples, IMF Working Paper, $\mathrm{WP} / 08 / 75$. 
Arrow, K. J. (1962). The Economic Implications of Learning by Doing, Review of Economic Studies, June, 29:2, 15573.

Asiedu, E. (2001). On the determinants of foreign direct investment in developing countries: is Africa different? World Development, 30(1), $107-119$.

Asiedu, E. (2003). Capital Controls and Foreign Direct Investment. World Development, 32(3), 479 - 490.

Ayadi, F. S. (2007). Foreign Direct Investment. Available at http://www.allbusiness.com. Retrieved: 16/11/2017.

Ayanwale A. B., \& Bamire, A. S. (2001). The Influence of Foreign Direct Investment on firm level productivity of Nigeria's Agro/Agro-allied sector.Final Report Presented to the African Economic Research Consortium, Nairobi, Kenya.

Ayanwale, A. B. (2007). FDI and economic growth, evidence from Nigeria. AERC Research Paper 165, African Economic Research Consortium, Nairobi.

Agarwal, J. (1980). Determinants of Foreign Direct Investment: A Survey. WeltwirtschaftlichesArchiv116, 739-773.

Athakorala, P. and Menon, J. (1995). Developing Countries with Foreign Investment: Malaysia. Australian Economic Review, 1:9-22.

Bai, J. and Perron, P. (2006). Multiple Structural Change Models: A Simulation Analysis, in Econometric Theory and Practice: Frontier of Analysis and Applied Research (Essays in Honor of Peter Phillips), ed. by Corbae, D., Durlauf, S. and Hansen, B.E., Cambridge University Press.

Balasubramanyam, V. N., Salisu, M. and Sapsford, D. (1996). Foreign Direct Investment and

Balasubramanyam, V. N. and Balasubramanyam, A., (2000). "The Software Cluster in Bangalore" in Dunning, J.H (Ed) Regions, Globalisation and the Knowledge -Based Economy, (Oxford University Press, London).

Banerjee, A., Dolado, J., Galbraith, J., and D. Hendry (2003).Co-integration, Error Correction, and the Econometric Analysis of Non-stationary Data: Advanced Text in Econometrics. New York: Oxford university press.

Belloumi, M. and Alshehry, A. (2018). The Impacts of Domestic and Foreign Direct Investments on Economic Growth in Saudi Arabia.Economies 2018, 6, 18; doi:10.3390/economies6010018.

Blomstrom, M. and Kokko, H. (2003). "The Economics of Foreign Direct Investment Incentives” NBER Working Paper, No. 9489.

Bosworth, and Collins, S. (1999). Capital Flows to Developing Economies; Implications for Saving and Investment. Brookings Papers on Economic Activity.

Borensztein, E., De Gregorio, J., and Lee, J-W. (1998). How Does Foreign Direct Investment Affect Economic Growth. Journal of International Economics, 45(1), 115-135.

Breusch, T. S. and Pagan, A. R. (1979). A Simple Test for Heteroscedasticity and Random Coefficient Variation, Econometrica 47, 1287- 1294.

Brooks, C. (2014). Introductory Econometrics for Finance 3rd Edition, Cambridge University Press.

Brown, R., Durbin, J., \& Evans, J. (1975). Techniques for testing the constancy of regression relationships over time. Journal of the Royal Statistical Society. Series B (Methodological), 149-192.

Brynard, P., A and Hanekom, S. X. (1997). Introduction to research in Public Administration

and related academic disciplines. Pretoria: J L Van Schaik Buckley, P. J. \& Casson, M. (1991). The Future of the Multinational Enterprise (London: Macmillan).

Caves, R. (1982; 1996). Multinational Firms and Economic Analysis. (1st and $2^{\text {nd }}$ editions) Cambridge, Cambridge University Press

Caves, R. (1982; 1996). Multinational Firms and Economic Analysis (1st and $2^{\text {nd }}$ Editions) Cambridge, Cambridge University Press.

Cleeves, E. (2005). How Effective are Fiscal Incentives to attract FDI to Sub-Saharan Africa? ECA Working Papers.

Charemza, W. and Deadman, D. (1992). New Directions in Econometric Practice: General to Specific Modelling, Cointegration and Vector Autoregression. Aldershot, Edward Elgar.

DeJong, D., Nankervis, J., Savin, N. and Whiteman, C. (1992). Integration Versus Trend Stationarity in Macroeconomic Time Series, Econometrica, 60, 423- 434.

de Mello, L. R. Jr. (1997). Foreign Direct Investment in Developing Countries and Growth: A Selective Survey, The Journal of Development Studies, 34:1, 1-34, DOI: 10.1080/00220389708422501

Dickey, D. A. and Fuller, W. A. (1979). Distribution of the estimators for autoregressive time series with a unit root, Journal of the American Statistical Association 74, 427-431.

Dunning, J. H. (1998). “Location and Multinational Enterprise: A Neglected Factor”, Journal of International Business Studies, Vol. 29, No. 1, pp. 46-66.

Dunning, J. H. (2002). Determinants of Foreign Direct Investment: Globalization Induced Changes and the Role of FDI Policies". Background Paper for the Annual Bank Conference on Development Economic held on Oslo, World Bank, Washington D.C. 
Elliott, G.; Rothenberg, T. J.; Stock, J. H. (1996). "Efficient Tests for an Autoregressive Unit Root". Econometrica. 64 (4): 813-836. JSTOR 2171846

Engle, R. F. and Granger, C.W. J. (1987). Co-integration and Error Correction: Representation, Estimation, and Testing, Econometrica, 55, pp. 251-76.

Federal Government of Nigeria, Executive Order No. 001 Of 2017 By The Acting President Of The Federal Republic Of Nigeria On the Promotion of Transparency and Efficiency in the Business Environment. https://pebec.gov.ng/wp-content/uploads/2017/07/EXECUTIVE-ORDER-ON-EASE-OF-DOINGBUSINESS-2017.pdf

Glynn, J, Perera, N and Verma, R (2007). Unit Root Tests and Structural Breaks: A Survey with Applications, Revista de Métodos Cuantitativos para la Economía y la Empresa. Journal of Quantitative Methods for Economics and Business Administration, 3(1), 2007, 63-79.

Granger, C. W. J. (1969). Investigating Causal Relations by Econometric Models and Cross-spectral Methods. Econometrica, Vol. 37, No. 3. (Aug., 1969), pp. 424-438.

Gregory, A. W. and Hansen, B. E. (1996). Residual-Based Tests for Cointegration in Models with Regime Shifts, Journal of Econometrics, Vol. 70, pp. 99-126.

Grossman, G. M. and Helpman, E. (1991). Quality Ladders in the Theory of Growth. The Review of Economic Studies, Vol. 58, No. 1. (Jan., 1991), pp. 43-61.

Grossman, G. M. and Helpman, E. (1994). Endogenous Innovation in the Theory of Growth, The Journal of Economic Perspectives, Vol. 8, No. 1. (Winter, 1994), pp. 23-44.

Hamilton, B. (2001). Using Engel's Law to Estimate CPI's Bias, American Economic Review, 91, 691 - 630.

Harrod, R. F. (1939). An Essay in Dynamic Theory. The Economic Journal, 49, 145-33

Hoang, T. T., Wiboonchutikula, P., \& Tubtimtong, B. (2010). Does Foreign Direct Investment Promote Economic Growth in Vietnam. ASEAN Economic Bulletin, 27(3), 295-311.

IMF, (1993). Balance of Payments Manual, Fifth Edition, Washington DC.

Jankowicz, A. (2000). Business Research Projects, 3rd Edition, Thomson Learning, London.

Jhingan, M. L. (2007). Economics of Development and Planning.35th edition. New Delhi: Vrinda Publication Ltd.

John, e. I. (2016). Effect of Foreign Direct Investment on Economic Growth in Nigeria, European Business \& Management, 2(2): 40-46. doi: 10.11648/j.ebm.20160202.14.

Kidanemariam, G. G. (2015). The Impact of Human Capital Development on Economic Growth in Ethiopia: Evidence from ARDL Approach to Co-Integration. Journal of Economics and Sustainable Development, Vol.6, No.13.

Koenker, R., 1981, A note on studentizing a test for heteroscedasticity, Journal of Econometrics 17, 107-l 12.

Kumar, A. (2007), Foreign Direct Investment Insights from the Federal Reserve Bank of Dallas; Vol. 2 No 1.

Kwiatkowski, D., Phillips, P. C. B., Schmidt, P. and Shin, Y. (1992). Testing the null hypothesis of stationarity against the alternative of a unit root. Journal of Econometrics. 54 (1-3): 159-178. doi:10.1016/0304-4076(92)90104Y.

Lucas, R. E. Jr. (1988). On the Mechanics of Economic Development, Journal of Monetary Economics, July, 22: 1, 342.

Makola, M. (2003), The Attraction of Foreign Direct Investment (FDI) by African countries. Proceedings of Biennial ESSA Conference. Sommerset West, Cape Town, September 17-19.

Miguel, D. R. (2000). Foreign Direct Investment in Mexico: A Cointegration Analysis. Journal of Development Studies, Vol. 37, No. 1, pp.138.

Morisset, J. (2000). Foreign Direct Investment in Africa: Policies also Matter. Transactional Corporation, 9, 107-25.

Morisset, J. (2001). "Foreign Direct Investment in Africa: Policies also Matter". GEED

Mwilima, N. (2003). Foreign Direct Investment in Africa. Social Observatory Pilot Project, Final Draft Report for the Labour Resource and Research Institute 29-45.

OECD, (1996): "OECD Benchmark Definition of Foreign Direct investment", Third Edition, Paris.

Olegan, J. O. (2000), Foreign Direct Investigation And Economic Growth In Nigeria; A Seemingly Unrelated Model African Review Of Money Finance And Banking, Pp.5-25. Milan, Italy.

Olokoyo, F. O. (2012). Foreign Direct Investment and Economic Growth: A Case Of Nigeria, BVIMSR 'SJournal Of Management Research, (April ) Vol. 4, No 1.

Onyeagu A. N. \& Okeiyika K. O. (2013). Investigating the interaction between foreign direct investment and human capital on growth: evidence from Nigeria. Asian Economic and Financial Review, 2013, 3(9):1134-1151.

Oyatoye, E. O., Arogundade, K. K., Adebisi, S. O., \& Oluwakayode, E. (2011). Foreign Direct Investment, Export and Economic growth in Nigeria of Humanities and Social Sciences, 2(1). 
Oyejide, T. A. (2005). Capital Flow and Economic Transformation: A Conceptual Framework. Proceedings of Central Bank of Nigeria 5th Annual Monetary Policy Conference, Abuja, Nov. 10th and $11^{\text {th }}$.

Ozturk, I. (2007). Foreign Direct Investment - Growth Nexus: A Review of the Recent Literature, International Journal of Applied Econometrics and Quantitative Studies Vol. 4-2.

Perron, P. (1989). The Great Crash, the Oil Price Shock, and the Unit Root Hypothesis.Econometrica 57: 1361-1401.

Perron, P. (1997). Further Evidence on Breaking Trend Functions in Macroeconomic Variables. Journal of Econometrics 80: 355-385.

Perron, P. and Vogelsang T. J. (1992). Nonstationary and Level Shifts with an Application to Purchasing Power Parity. Journal of Business and Economic Statistics 10: 301-320.

Pesaran, M.H. and Shin, Y. (1999). An Autoregressive Distributed Lag Modelling Approach to Cointegration Analysis. Econometrics and Economic Theory in the 20th Century: The Ragnar Frisch Centennial Symposium, Strom, S. (ed.) Cambridge University Press.

Pesaran, H., Shin, Y. and Smith, R. (2001). Bounds Testing Approaches to the Analysis of Level Relationships", Journal of Applied Econometrics, special issue in honour of J. Sargan on the theme "Studies in Empirical Macroeconometrics", (eds.) D. Hendry and M. Pesaran, Vol.16.

Roderick, D. (2000). Trade policy and Economic Growth: a Skeptic's Guide to the Cross-national Evidence, National Bureau of Economic Research Working Paper No. 7081, Washington.

Romer, P. M. (1986). Increasing Returns and Long-Run Growth, Journal of Politcal Economy, October, 94:5, 1002-37. Romer, Paul M., (1990). Endogenous Technological Change, Journal of Political Economy, October, Part 2, 98:5, S71102.

Salisu, A. A. and Oloko, T. (2015). Modeling Oil Price-US Stock Nexus: A VARMA-BEKK-AGARCH approach, Energy Economics, Elsevier, 50, 1 - 12.

Schneider, F. and Frey, B. (1985) Economic and Political Determinants of Foreign Direct Investment, World Development 13, 161-174.

Shafaeddin, S. M. (2005). Trade Liberalization and Economic Reform In Developing Countries, Structural Change or De-Industrialization? Discussion Paper, No. 179,United Nations Conference on Trade and Development, Geneva.

Shell, K. (1966). Toward a Theory of Inventive Activity and Capital Accumulation, A.E.R. Papers and Proc. 56 (May): 62-68.

Tervio, M. (2002). Does Trade Raise Income? Evidence from the Twentieth Century. Journal of International Economics, 58, 1-18

Trinh, N. H. and Nguyen, Q. A. M. (2015). The Impact of Foreign Direct Investment on Economic Growth: Evidence from Vietnam.

Ugochukwu, U. S., Okore, A. O. and Onoh, J. O. (2013). The Impact of Foreign Direct Investment on the Nigerian Economy, European Journal of Business and Management, Vol.5, No.2.

Umoh, O. J., Jacob, A. O. and Chuku, A. C. (2012). Foreign Direct Investment and Economic Growth in Nigeria: An Analysis of the Endogenous Effects, Current Research Journal of Economic Theory 4(3): 53-66, 2012.

UNCTAD (2000) World |Investment Report, Cross- Border Mergers and Acquisitions and Development (United Nations, New York)

UNCTAD (2001) World Investment Report, Promoting Linkages (United Nations, New York,) World Bank (2002).Global Development Finance. Washington, DC: World Bank. www.idpublications.org

Virmani, V. (2001). Unit Root Tests: Results from Some Recent Tests Applied to Select Indian Macroeconomic Variables. Indian Institute of Management, 3-5. Available from: http://www.iimahd.ernet.in/publications/data/2004-02-04vineet.pdf.

Wei, W. (2016). Vertical specialization and enlarging the size of the economy: Comparing impacts of conventional trade and processing trade patterns on GDP growth in China. Chapter 3 in Achieving Inclusive Growth in China Through Vertical Specialization, pp. 15-69. https://doi.org/10.1016/B978-0-08-100627-6.00003-5

Weisbrot, M., \& Baker, D. (2002). The Relative Impact of Trade Liberalization on Developing Countries. Centre For Economic and Policy Research, Washington, D.C.

Yakubu, M. M. and Akanegbu, B. N. (2014). European Journal of Business, Economics and Accountancy Vol. 3, No. 6, 2015 ISSN 2056-6018 Progressive Academic Publishing, UK p. 26

Zivot, E. and Andrews, D. W. K. (1992). Further Evidence on the Great Crash, the Oil-Price Shock, and the Unit-Root Hypothesis, Journal of Business \& Economic Statistics, Vol. 10, No. 3, pp. 251-270. 